Article

\title{
Indication of Groundwater Contamination Using Acesulfame and Other Pollutants in a Rural Area of Korea
}

\author{
Chung-Mo Lee ${ }^{1}$, Se-Yeong Hamm ${ }^{1, *} * \mathbb{D}$, Sul-Min Yun ${ }^{1}$, Jeong-Eun $\mathrm{Oh}^{2}{ }^{2}$, MoonSu Kim ${ }^{3}{ }^{\circledR}$ and \\ Hyun Koo Kim ${ }^{3}$ \\ 1 Department of Geological Sciences, Pusan National University, Busan 46241, Korea; \\ lcmo1006@naver.com (C.-M.L.); ehdls92@naver.com (S.-M.Y.) \\ 2 Department of Civil and Environmental Engineering, Pusan National University, Busan 46241, Korea; \\ jeoh@pusan.ac.kr \\ 3 Soil and Groundwater Division, National Institute of Environmental Research, Incheon 22689, Korea; \\ hyd009@korea.kr (M.S.K.); khk228@korea.kr (H.K.K.) \\ * Correspondence: hsy@pusan.ac.kr; Tel.: +82-51-510-2252
}

Received: 1 October 2018; Accepted: 21 November 2018; Published: 26 November 2018

\begin{abstract}
Approximately 40,000 chemical products are currently used in Korea; these products can contaminate the groundwater/soil, the surrounding environment, and organisms for extended periods of time. In this study, a hydrological field survey, a water quality analysis, and groundwater modeling were performed to identify the source and transport path of pollution that was caused by inorganic matter and artificial sweeteners, especially acesulfame, in the groundwater of an agricultural area in Chungnam Province, Korea. In the study area, a higher concentration of acesulfame displayed a spatial distribution similar to nitrate-nitrogen concentration. The characteristics of the groundwater flow and the distribution of the acesulfame were simulated using the Visual MODFLOW Classic Interface ver. 2014.1 and the MT3DMS module, respectively. The modeled area was divided into hilly (southern), residential (northwest), and agricultural (northeast) zones. The stream's boundary was set to be the drainage channel in the southern hilly zone. From the simulation, we found that acesulfame spread actively from the source for 1-3 years before it reached equilibrium in the northern part of the model domain (the area downstream of the stream's boundary). The concentration of acesulfame in the agricultural zone of the model domain decreased after five years, and it reached the steam boundary and residential zone within 10 years. After 10 years, most of the acesulfame was discharged from the agricultural zone and the hilly zone, while the concentration in the residential zone was approximately the same. Acesulfame is considered to be a potential indicator of man-made contamination for use in the management of groundwater quality.
\end{abstract}

Keywords: rural area; acesulfame; artificial sweeteners; groundwater modeling; pollution indicator

\section{Introduction}

With the development of industries, the use of a diverse range of chemicals has increased and presents an environmental contamination risk. Since 2009, the residues of artificial sweeteners in the environment have been actively investigated using various water samples, including sewage water, wastewater, river water, and groundwater [1,2]. Research on artificial sweeteners as indicators of wastewater has continuously been carried out [3]. Table 1 shows the concentrations of artificial sweeteners, such as acesulfame, cyclamate, saccharin, and sucralose, in groundwater in some countries [4-8]. Acesulfame, which has low adsorption in soil due to its high solubility and low adsorption [2] and is highly persistent due to the low biodegradation during sewage treatment [5,9-11], 
is known to be a pollutant in groundwater and surface water due to sewage inflow [12,13]. The Swiss Federal Research Center for Agroecology and Agriculture in Zurich has reported that acesulfame is a highly persistent material that is detected in high concentrations in the environment and can be used to track wastewater. In Switzerland, the acesulfame that had not been eliminated from the wastewater treatment plants, and was quite persistent in surface waters, showed an increased concentration with a high density of population in the catchment area and a decreased concentration in the water throughflow area, and it was consistently detected in untreated and treated wastewater samples $(12-46 \mu \mathrm{g} / \mathrm{L})$, in most surface waters samples, in $65 \%$ of the investigated groundwater samples, and even in several tap water samples (up to $2.6 \mu \mathrm{g} / \mathrm{L}$ ).

Table 1. The concentration of artificial sweeteners in groundwater in some countries.

\begin{tabular}{lccccc}
\hline & E.U. [4] & Switzerland [5] & Germany [6] & U.S. [7] & Serbia [8] \\
\hline Acesulfame & - & $0.2-6.9$ & $0.4-1.1$ & - & $0.09-0.31$ \\
Cyclamate & - & - & $0.01-0.13$ & - & $0.09-0.13$ \\
Saccharin & - & - & $0.01-3.8$ & - & $0.006-0.08$ \\
Sucralose & $<0.01-0.092$ & $<$ LOD-0.6 & $<$ LOQ-0.1 & $0.0008-2.0$ & $<$ LOQ \\
\hline
\end{tabular}

LOD: Limit Of Detection, LOQ: Limit Of Quantification.

Medicinal substances in groundwater have been studied in European countries, the United States, China, etc. [14-18]. Some medicinal materials have also been studied in Korea $[19,20]$. The use of veterinary medicines, which leave residues in the environment, is increasing [21]. Numerous studies [22-24] have focused on antibiotics, since antibiotic-resistant bacteria have continuously been detected in the environment. In 2011, the World Health Organization (WHO) [25] highlighted the need for studies monitoring the spread of antibiotics and their propagation pathways. Antibiotics in animals account for approximately $50 \%$ of the total antibiotic use worldwide [26]. In the U.S., between 6350 and 13,380 tons of antibiotics are used on farm animals each year [27]. Bartelt-Hunt et al. [28], Batt et al. [29], Hu et al. [22], and Watanabe et al. [30] studied the animal medicinal substances found in groundwater that was collected from animal husbandry farms and detected antibiotics, such as sulfonamides, microlides, and tetracyclines. In particular, sulfamethazine, a sulfonamide antibiotic, was detected at a relatively high concentration along with monensin, a feed additive, and hormonal drugs. Barnes et al. [31] found various medicinal substances, including antibiotics and hormones, in $80 \%$ of river water samples and $95 \%$ of groundwater samples. In particular, in 2002, a high concentration of sulfamethazine was found in the groundwater in agricultural and livestock areas.

Nitrate, which is one of the most common inorganic pollutants in groundwater, creates a significant water-quality problem in diverse land-use areas, especially in agricultural regions [32]. Nitrate in groundwater originates from non-point sources like inorganic fertilizers and point sources like sewage from septic tanks and animal/human excrement [33-35]. Kim et al. [36] reported the significant potential of nitrate pollution in groundwater by the application of nitrogen fertilizer ( $>250 \mathrm{~N} \mathrm{~kg} / \mathrm{ha}$ ) in agricultural areas of Korea. Cheong et al. [37] characterized nitrate contamination in groundwater in the Gimpo agricultural area in Korea, by using a risk assessment method.

In Korea, the residual status, the behavioral characteristics, and the risk assessment of medicinal substances have been studied by investigating livestock and marine products, as well as the environment $[38,39]$. In particular, the National Institute of Environmental Research (NIER) has studied the residual state and behavior of medicinal substances in the environment several times. For instance, between 2008 and 2011, they monitored medicinal substances in water systems and surveyed the production/use of medicines in Korea through an 'Investigation on the residual status and the chemical analysis methodology of residual medicinal substances'. In the context of this investigation, 40 medicinal chemicals, including analgesics, antipyretics, anti-inflammatories, disinfectants, anti-depressants, and beta-blockers for human use, antibiotics, antimicrobials, analgesics, 
antipyretics, and anti-inflammatories for human/animal use, and antibiotics and antimicrobials for animal use, were surveyed in groundwater [40,41].

Korea's Groundwater Act prescribes 19 water quality standards for 19 chemicals including nitrate nitrogen (nitrate-N) [42]; however, it needs to include more water quality standards for medicinal substances, artificial sweeteners, pesticides, etc. The NIER [43] found two representative indicators among the drinking water quality standards for agricultural areas in Korea: nitrate- $\mathrm{N}$ and the total coliform group. Korea's Animal and Plant Quarantine Agency conducted a survey on the behavior of drugs for animals in the soil and groundwater around livestock farms for two years (2009-2010) and, in the groundwater around pig and poultry farms, found a high concentration of medicinal substances for livestock, such as sulfamethazine and sulfonamide-based antibiotics [20].

This study examined the characteristics and distribution of acesulfame and other pollutants in the groundwater in a rural area in Chungnam Province, Korea. For this study, groundwater samples from eight wells were collected three times in 2017. Water quality analyses (cations, ions, and artificial sweeteners), a hydrogeological survey (a slug test and a tracer test), a grain size analysis, and groundwater modeling were carried out. Temperature, $\mathrm{pH}$, and electrical conductivity (EC) were measured in the field. $\mathrm{K}^{+}, \mathrm{Na}^{+}, \mathrm{Ca}^{2+}, \mathrm{Mg}^{2+}, \mathrm{HCO}_{3}{ }^{-}, \mathrm{CO}_{3}{ }^{2-}, \mathrm{SO}_{4}{ }^{2-}, \mathrm{Cl}^{-}$, acesulfame, cyclamate, and saccharin were analyzed in the laboratory. For this study, nitrate- $\mathrm{N}$ concentrations by the previous study [43] were also compared with the acesulfame concentrations.

\section{Materials and Methods}

The study area, $\mathrm{S}$ village in O Myeon, Buyeo-gun, Chungcheongnam-do province, is composed of a hilly zone (southern part of study area) at an altitude of $\sim 230 \mathrm{~m}$ above the mean seal level (a m.s.l.), a residential zone that is 20-40 $\mathrm{m}$ a m.s.l., and an agricultural zone that is $0-20 \mathrm{~m}$ a m.s.l. Streams flow from the south to the northeast. The main pollution sources are the farmland, surrounding sloped forest orchards that mostly produce chestnuts and one livestock farm that uses composted manure. The total watershed has an area of $458,567 \mathrm{~m}^{2}$. Farmland covers $226,466 \mathrm{~m}^{2}$, which is $49.6 \%$ of the total area; this farmland is $70 \%$ paddies, $18 \%$ dry agricultural land, and $12 \%$ orchard [43]. Rice, garlic, sesame, onions, potatoes, sweet potatoes, etc., are cultivated in the agricultural area. Eight wells (BS-3, BS-5, BS-6, BS-8, BS-9, BS-M1, BS-M2, and BS-M3) were sampled three times in May, August, and October in 2017 (Figure 1).

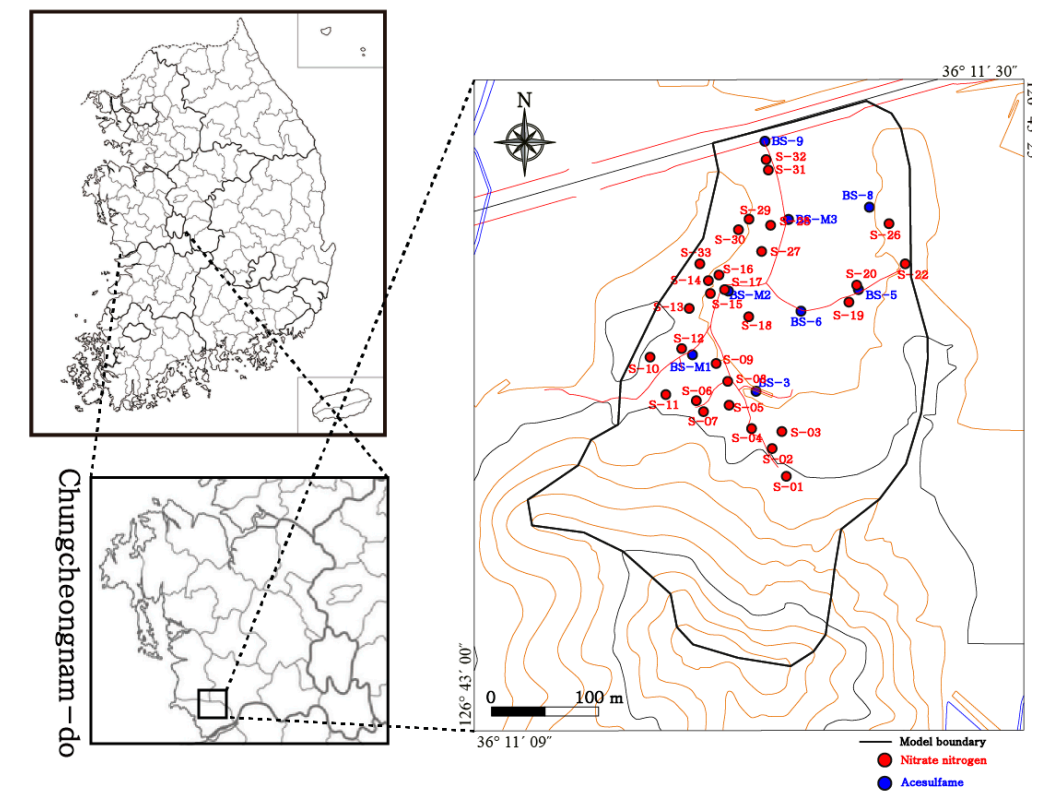

Figure 1. The location of the study area and the wells that were investigated for acesulfame and nitrate-N. 


\subsection{Water Quality Analysis}

Groundwater samples from eight wells were collected for a laboratory analysis with the physicochemical components ( $\mathrm{pH}, \mathrm{EC}$, and water temperature) in a stabilized state and at the same locations for an in situ water quality analysis (Figure 1). The samples were filtered using $45-\mu \mathrm{m}$ filter paper. In addition, the samples that were used for a cation analysis were treated with a $0.05 \mathrm{~N}$ nitric acid solution in order to prevent the adsorption of the cations on the sample bottle. The filtered samples were stored in 200-mL sterilized bottles and refrigerated at or below $4{ }^{\circ} \mathrm{C}$ as they were transported to the laboratory for analysis. Four cations $\left(\mathrm{K}^{+}, \mathrm{Na}^{+}, \mathrm{Ca}^{2+}\right.$, and $\left.\mathrm{Mg}^{2+}\right)$ and four anions $\left(\mathrm{HCO}_{3}{ }^{-}, \mathrm{CO}_{3}{ }^{2-}\right.$, $\mathrm{SO}_{4}{ }^{2-}$, and $\mathrm{Cl}^{-}$) in the groundwater samples were analyzed by using an inductively-coupled plasma atomic emission spectrometer (Model ICP-IRIS, Thermo Jarrell Ash Co., Cambridge, MA, USA) and ion chromatography (Model DX-500, Dionex Co., Sunnyvale, CA, USA), respectively, in the Core Research Facilities at Pusan National University (PNU). We also analyzed the artificial sweeteners acesulfame, cyclamate, and saccharin. The artificial sweeteners and the triclosan were analyzed by using an Agilent 1200 HPLC (Agilent Technologues, Santa Clara, CA, USA) for liquid chromatography, and an Agilent 6460 triple-quadrupole mass spectrometer (Agilent Technologues, Santa Clara, CA, USA) for detection, in the laboratory of the Department of Environmental Engineering at PNU (Table 2).

Table 2. The laboratory analysis of the artificial sweeteners and the triclosan (negative mode).

\begin{tabular}{|c|c|c|c|c|c|c|c|}
\hline \multicolumn{8}{|c|}{ Conditions } \\
\hline \multirow{7}{*}{$\mathrm{LC}$} & Column & \multicolumn{6}{|c|}{ ZORBAX Eclipse XDB-C18 $(4.6 \times 150 \mathrm{~mm}, 3.5 \mu \mathrm{m})$} \\
\hline & Column temp. & \multicolumn{6}{|c|}{$40^{\circ} \mathrm{C}$} \\
\hline & Mobile-phase & \multicolumn{6}{|c|}{$\begin{array}{l}\text { A: } 5 \mathrm{mM} \text { ammonium acetate in methanol } \\
\text { B: } 5 \mathrm{mM} \text { ammonium acetate in water }\end{array}$} \\
\hline & Flow rate & \multicolumn{6}{|c|}{$0.4 \mathrm{~mL} / \mathrm{min}$} \\
\hline & \multirow{2}{*}{ Gradient program } & Min & 0 & 1 & 4 & 16.9 & 17 \\
\hline & & $\mathrm{B}(\%)$ & 60 & 60 & 10 & 01 & 60 \\
\hline & Injection vol. & & & & & & \\
\hline \multirow{7}{*}{ MS/MS } & Ionization mode & \multicolumn{6}{|c|}{ Negative ion electrospray } \\
\hline & Gas temp. & \multicolumn{6}{|c|}{$250^{\circ} \mathrm{C}$} \\
\hline & Gas flow rate & \multicolumn{6}{|c|}{$10 \mathrm{~L} / \mathrm{min}$} \\
\hline & Sheath gas temp. & \multicolumn{6}{|c|}{$380^{\circ} \mathrm{C}$} \\
\hline & Sheath gas flow rate & \multicolumn{6}{|c|}{$10 \mathrm{~L} / \mathrm{min}$} \\
\hline & Capillary voltage & \multicolumn{6}{|c|}{$4000 \mathrm{~V}$} \\
\hline & Nebulizer pressure & \multicolumn{6}{|c|}{$40 \mathrm{psi}$} \\
\hline
\end{tabular}

\subsection{Hydrogeological Survey}

Hydraulic conductivity can be determined by using hydraulic field tests for bedrock aquifers, such as a pumping test, a slug test, and a water pressure test, and hydraulic field tests for unconsolidated formations, such as a con penetration test [44-46], a pumping test [47,48], a slug test, and a grain size analysis [49]. Specifically, the hydraulic conductivity of contaminated soils can be evaluated by $[50,51]$. In this study, the hydraulic conductivity values were determined by a using grain size analysis and a slug test. Besides this, a tracer test was carried out to estimate the longitudinal dispersivity and the velocity of solutes.

\subsubsection{The Grain Size Analysis and the Slug Test}

A sieve analysis of dry grains was performed using sieve numbers of up to $200(0.074 \mathrm{~mm})$, and the size of grains that were smaller than $0.074 \mathrm{~mm}$ was determined using a laser grain size analysis. 
First, the samples were sifted in order of grain size, and then, the material that passed through the sieves was weighed. Table 3 shows the sieve numbers and the mesh sizes that were used in this study.

Table 3. The sieve numbers and mesh sizes.

\begin{tabular}{ccccccccc}
\hline Sieve No. & 8 & 10 & 20 & 40 & 60 & 100 & 140 & 200 \\
\hline Mesh size $(\mathrm{mm})$ & 2.36 & 2 & 0.84 & 0.425 & 0.25 & 0.15 & 0.105 & 0.074 \\
\hline
\end{tabular}

The hydraulic conductivity, $K\left(\mathrm{LT}^{-1}\right)$, can be estimated using four empirical formulas (Table 4 ) that follow from the grain size analysis based on Equation (1) [52]:

$$
K=\left(\frac{g}{\mu}\right) \times \beta \times v(n) \times d_{e}^{2}
$$

where $g$ is the gravitational acceleration $\left(\mathrm{LT}^{-2}\right) ; \mu$ is the kinematic viscosity $\left(\mathrm{L}^{2} \mathrm{~T}^{-1}\right)$; $\beta$ is a dimensionless coefficient that depends on the texture, particle shape, rock composition, anisotropy, etc.; $v(n)$ is the porosity function; $n$ is the porosity (dimensionless); and $d_{e}$ is the effective diameter of the porous medium (L). In this study, the $\mu$ value of groundwater was applied based on the average temperature of groundwater $\left(15^{\circ} \mathrm{C}\right)$.

Table 4. The empirical formulas for the grain size analysis.

\begin{tabular}{ccccc}
\hline Author & $\boldsymbol{\beta}$ & $\boldsymbol{v}(\boldsymbol{n})$ & $\boldsymbol{d}_{\boldsymbol{e}}$ & Grain Range \\
\hline Hazen [53] & $6 \times 10^{-4}$ & $(1+10(\mathrm{n}-0.26))$ & $\mathrm{d}_{10}$ & $0.1 \mathrm{~mm}<d_{e}<3 \mathrm{~mm}, U<5$ \\
\hline Beyer [54] & $6 \times 10^{-4} \log (500 / \mathrm{C})$ & 1 & $\mathrm{~d}_{10}$ & $0.06 \mathrm{~mm}<d_{e}<0.6 \mathrm{~mm}, 1<U<20$ \\
\hline Kozeny [55] & $8.3 \times 10^{-3}$ & $\mathrm{n}^{3} /(1-\mathrm{n})^{2}$ & $\mathrm{~d}_{10}$ & Coarse sand \\
\hline Sauerbrei [56] & $3.75 \times 10^{-3}$ & $\mathrm{n}^{3} /(1-\mathrm{n})^{2}$ & $\mathrm{~d}_{17}$ & Sand and sandy clay, $d_{e}<0.5 \mathrm{~mm}$ \\
\hline & $U: \frac{d_{60}}{d_{10}}$. & &
\end{tabular}

A slug test is a cost-effective hydraulic field test that is used to obtain the hydraulic parameters. During the test, a dummy or water is instantaneously inserted into the water of the borehole, and the change in the water level is measured. From the moment when the dummy rises above the water, the water level recovery is measured. Hydraulic parameters are commonly estimated using the Hvorslev [57], Bower and Rice [58], or Cooper-Bredehoeft-Papadopulos [59] method.

\subsubsection{Tracer Test}

Common tracers in groundwater surveys include chloride $\left(\mathrm{Cl}^{-}\right)$, bromide $\left(\mathrm{Br}^{-}\right)$, lithium $\left(\mathrm{Li}^{+}\right)$, ammonium $\left(\mathrm{NH}_{4}{ }^{+}\right)$, magnesium $\left(\mathrm{Mg}^{2+}\right)$, potassium $\left(\mathrm{K}^{+}\right)$, iodide $\left(\mathrm{I}^{-}\right)$, and sulfate $\left(\mathrm{SO}_{4}{ }^{2-}\right)$. The dye tracers fluorescein, pyranine, lissamine FF, rhodamine $\mathrm{B}$, rhodamine $\mathrm{WT}$, and sulfo-rhodamine $\mathrm{B}$ have high detectability, enable rapid field analysis, are low cost, and have low toxicity [60].

In this study, a natural gradient tracer test was used, which is one of the multi-well tracer tests. The test needs one injection well and at least one observation well. For the test, a small amount of tracer is inserted into the aquifer in order to monitor its transport through the natural groundwater flow. In principle, the observation and injection wells should be arranged perpendicular to the direction of flow. However, this method is not suitable if there is a long distance between the injection and observation wells. The equation used for the tracer test analysis using TRAC ver. 1.7 [61] is:

$$
C(x, t)=\frac{M_{0}}{A_{\omega}}\left[\frac{2}{\sqrt{4 \pi D_{L} T}} \exp \left(-\frac{(-u t)^{2}}{4 D_{L} t}\right)-\frac{\mu}{2 D_{L}} \exp \left(\frac{u x}{D_{L}}\right) \operatorname{erfc}\left(\frac{(x+u t)}{\sqrt{4 D_{L} T}}\right)\right] \exp (-\lambda t)
$$


where $M$ is the injection tracer's mass $(\mathrm{kg}), u$ is the pore water velocity $(\mathrm{m} / \mathrm{s}), A$ is the groundwater flow section $\left(\mathrm{m}^{2}\right), \omega$ is the effective porosity $(0<\omega<1), D_{L}$ is the longitudinal dispersion coefficient $\left(\mathrm{m}^{2} / \mathrm{s}\right), \operatorname{erfc}$ is the error function, $t$ is time, $r$ is the radial distance $(\mathrm{m}), x$ is the distance between the injection and monitoring wells along the $x$-axis $(\mathrm{m})$, and $\lambda$ is the decay constant $(1 / \mathrm{s})$.

\subsection{Groundwater Modeling}

Groundwater modeling simulates the groundwater flow in porous or fractured saturated media in order to estimate or predict the groundwater quantity and/or quality in aquifers in steady and transient states. The world's most popular software for groundwater modeling is Visual MODFLOW. It uses the finite difference method that is equipped by MODFLOW [62] and simulates the solute transport of non-reactive and reactive chemical constituents in 3D using the MT3DMS [63] and RT3D [64] packages. The MT3DMS package can precisely describe the transport of miscible contaminants in groundwater and takes into account advection, dispersion, and diffusion, as well as some basic chemical reactions. Various boundary conditions and external sources or sinks can be applied, and it is able to interpret the spatial concentrations of bio-chemical reactive multi-species pollutants such as BTEX (Benzene, Toluene, Ethylbenzene, Xylene) and chlorinated organic materials. The basic equation for non-reactive and reactive solute transport is:

$$
\frac{\partial C_{k}}{\partial t}=\frac{\partial}{\partial x_{i}}\left(D_{i, j} \frac{\partial C_{k}}{\partial x_{i}}\right)-\frac{\partial}{\partial x_{i}}\left(v_{i} C_{k}\right)+\frac{q_{s}}{\Phi} C_{s k}+\sum_{k=1}^{N} r_{c}, k=1,2,3 \ldots
$$

where $C_{k}$ is the concentration of pollutants in the groundwater; $r$ is the species reaction term; $t$ is time $(\mathrm{T}) ; x_{i}$ is the coordinate distance $(\mathrm{L}) ; D_{i}$ is the hydraulic dispersion coefficient $\left(\mathrm{L}^{2} \mathrm{~T}^{-1}\right) ; v_{i}$ is the void flow rate $\left(\mathrm{LT}^{-1}\right) ; q_{s}$ is the volumetric flux, with a positive value for sources and a negative value for sinks; $\mathrm{C}_{s k}$ is the concentration of sources and sinks; and $r_{c}$ is the chemical reaction term (adsorption, biodegradation, etc.).

Particle tracking is a simple method that is commonly used to estimate the groundwater flow and contaminant pathways and to approximate the transport of contaminants by advection without using the complex MT3DMS and RT3D packages. Traditionally, particle tracking by the first-order Euler algorithm is given by:

$$
x^{n+1}=x^{n}+\frac{\Delta t}{R} v_{x}\left(x^{n}, y^{n}, z^{n}\right), y^{n+1}=y^{n}+\frac{\Delta t}{R} v_{y}\left(x^{n}, y^{n}, z^{n}\right), z^{n+1}=z^{n}+\frac{\Delta t}{R} v_{z}\left(x^{n}, y^{n}, z^{n}\right)
$$

where $x^{n+1}, y^{n+1}$, and $z^{n+1}$, as well as $x_{n}, y_{n}$, and $z_{n}$ are the coordinates $x, y$, and $z$ of the particles at the $(n+1)$ th step and the $n$th step, respectively; $\mathrm{v}_{x}, v_{y}$, and $v_{z}$ are the linear velocities of the particles at the $n$th step; $R$ is the retardation factor of the adsorption reaction in the solute transport equation; and $\Delta t$ is the time step range of the solute behavior, which is usually determined by Equation (5), the Courant condition:

$$
|\Delta t| \leq \gamma_{c} R \times \operatorname{MIN}\left(\frac{\Delta t}{v_{x}}, \frac{\Delta y}{v_{y}}, \frac{\Delta z}{v_{z}}\right)
$$

where $\gamma_{c}$ is the Courant number, which is the number of cells and represents the transport distance of one particle in any direction during one time step of forward particle tracking for positive $\Delta t$ values and backward particle tracking for negative $\Delta t$ values. Forward particle tracking chiefly predicts the range across which the contaminant will spread from a known source, while backward particle tracking is used to identify the source and transport pathway of a contaminant when the source is unidentified.

In this study, Visual MODFLOW software was used to simulate the groundwater flow and the acesulfame transport in the study area. 


\section{Results}

\subsection{Water Quality}

The physicochemical component $\mathrm{pH}$ displayed a mean values of 6.01 with minimum (5.43) at BS-M2 and the maximum (6.86) at BS-M3. The physicochemical components EC displayed a mean value of $468 \mu \mathrm{S} / \mathrm{cm}$ with the minimum $(172 \mu \mathrm{S} / \mathrm{cm})$ at BS-3 and maximum $(919 \mu \mathrm{S} / \mathrm{cm})$ at BS-9. The groundwater types were classified into the $\left[\mathrm{Ca}-\mathrm{HCO}_{3}\right]$ type, which was dominant in the residential zone, and the $\left[\mathrm{Na}-\mathrm{HCO}_{3}\right]$ type, which was dominant in the agricultural zone (Table 5).

Table 5. The physicochemical properties and the groundwater types in the residential and agricultural zones.

\begin{tabular}{|c|c|c|c|c|c|c|}
\hline & \multirow{2}{*}{\multicolumn{2}{|c|}{ Well No. }} & $\mathbf{T}$ & $\mathrm{pH}$ & EC & Water Type \\
\hline & & & ${ }^{\circ} \mathrm{C}$ & - & $\mu \mathrm{S} / \mathrm{cm}$ & \\
\hline \multirow{12}{*}{ Residential zone } & \multirow{3}{*}{ BS-3 } & 1 st & 16.0 & 5.56 & 172 & $\mathrm{Na}-\mathrm{HCO}_{3}$ \\
\hline & & 2nd & 19.1 & 5.98 & 584 & $\mathrm{Na}-\mathrm{Cl}$ \\
\hline & & $3 \mathrm{rd}$ & 17.2 & 6.03 & 231 & $\mathrm{Na}-\mathrm{HCO}_{3}$ \\
\hline & \multirow{3}{*}{ BS-M1 } & 1 st & 18.0 & 6.12 & 393 & $\mathrm{Ca}-\mathrm{HCO}_{3}$ \\
\hline & & 2nd & 19.8 & 6.66 & 555 & $\mathrm{Ca}-\mathrm{HCO}_{3}$ \\
\hline & & $3 \mathrm{rd}$ & 16.3 & 6.34 & 615 & $\mathrm{Ca}-\mathrm{HCO}_{3}$ \\
\hline & \multirow{3}{*}{ BS-M2 } & $1 \mathrm{st}$ & 17.31 & 5.43 & 272 & $\mathrm{Ca}-\mathrm{HCO}_{3}$ \\
\hline & & 2nd & 18.75 & 5.88 & 242 & $\mathrm{Ca}-\mathrm{HCO}_{3}$ \\
\hline & & $3 \mathrm{rd}$ & 16.83 & 5.94 & 277 & $\mathrm{Ca}-\mathrm{NO}_{3}$ \\
\hline & \multirow{3}{*}{ BS-M3 } & 1 st & 16.38 & 6.09 & 575 & $\mathrm{Ca}-\mathrm{HCO}_{3}$ \\
\hline & & 2nd & 21.5 & 6.86 & 799 & $\mathrm{Ca}-\mathrm{HCO}_{3}$ \\
\hline & & $3 \mathrm{rd}$ & 16.2 & 6.02 & 649 & $\mathrm{Ca}-\mathrm{HCO}_{3}$ \\
\hline \multirow{12}{*}{ Agricultural zone } & \multirow{4}{*}{ BS-5 } & 1 st & 17.46 & 5.47 & 330 & $\mathrm{Na}-\mathrm{HCO}_{3}$ \\
\hline & & 2nd & 20.5 & 5.87 & 539 & $\mathrm{Na}-\mathrm{HCO}_{3}$ \\
\hline & & $3 r d$ & 18.8 & 5.52 & 373 & $\mathrm{Na}-\mathrm{HCO}_{3}$ \\
\hline & & 1 st & 17.94 & 6.31 & 288 & $\mathrm{Na}-\mathrm{HCO}_{3}$ \\
\hline & \multirow[t]{3}{*}{ BS-6 } & 2nd & 19.08 & 5.78 & 412 & $\mathrm{Na}-\mathrm{HCO}_{3}$ \\
\hline & & $3 r d$ & 17.6 & 5.77 & 344 & $\mathrm{Ca}-\mathrm{HCO}_{3}$ \\
\hline & & $1 \mathrm{st}$ & 16.9 & 5.99 & 428 & $\mathrm{Na}-\mathrm{NO}_{3}$ \\
\hline & \multirow[t]{3}{*}{ BS-8 } & 2nd & 19.05 & 6.08 & 545 & $\mathrm{Na}-\mathrm{NO}_{3}$ \\
\hline & & $3 \mathrm{rd}$ & 17.4 & 5.74 & 390 & $\mathrm{Na}-\mathrm{NO}_{3}$ \\
\hline & & $1 \mathrm{st}$ & 17.05 & 6.13 & 597 & $\mathrm{Ca}-\mathrm{Cl}$ \\
\hline & \multirow[t]{2}{*}{ BS-9 } & 2nd & 19.18 & 6.22 & 919 & $\mathrm{Ca}-\mathrm{Cl}$ \\
\hline & & $3 \mathrm{rd}$ & 17.1 & 6.51 & 713 & $\mathrm{Ca}-\mathrm{HCO}_{3}$ \\
\hline Min. & & & 16.0 & 5.43 & 172 & \\
\hline Max. & & & 21.5 & 6.86 & 919 & \\
\hline Mean & & & 18.0 & 6.01 & 468 & \\
\hline
\end{tabular}

Groundwater samples were collected from the eight wells BS-3, BS-5, BS-6, BS-8, BS-9, BS-M1, BS-M2, and BS-M3 for analyses in May, August, and October 2017. Acesulfame was detected in all eight samples from the first, second, and third surveys, with mean values of $102 \mathrm{ng} / \mathrm{L}(8.1-345 \mathrm{ng} / \mathrm{L})$, $577 \mathrm{ng} / \mathrm{L}$ (17.3-2695 ng/L), and $214 \mathrm{ng} / \mathrm{L}$ (10.3-764 ng/L), respectively (Table 6). Cyclamate was detected in all eight samples from the first survey with a mean value of $249 \mathrm{ng} / \mathrm{L}(13.5-860 \mathrm{ng} / \mathrm{L})$; however, it was only detected in the BS-M1 sample from the second survey and in the BS-9 and BS-M1 samples from the third survey. Saccharin was detected in some of the samples from the first survey, while it was detected in all eight samples from the second and third surveys with mean values of $257 \mathrm{ng} / \mathrm{L}$ (68.1-1156 ng/L) and $134 \mathrm{ng} / \mathrm{L}$ (12.7-236 ng/L), respectively. 
Table 6. The concentrations of artificial sweeteners and agrichemicals (unit: ng/L).

\begin{tabular}{cccccccccc}
\hline \multirow{2}{*}{ Constituents } & \multicolumn{4}{c}{ Residential Zone } & \multicolumn{3}{c}{ Agricultural Zone } \\
\cline { 3 - 10 } & & BS-3 & BS-M1 & BS-M2 & BS-M3 & BS-5 & BS-M6 & BS-8 & BS-9 \\
\hline \multirow{3}{*}{ Acesulfame } & 1st & 25.8 & 40.4 & 8.1 & 345 & 17.9 & 11.7 & 38.1 & 330 \\
& 2nd & 108 & 89.7 & 23.5 & 1408 & 120 & 17.3 & 156 & 2695 \\
& 3rd & 13.9 & 764 & 10.3 & 47.4 & 55.7 & 11.3 & 88.5 & 720 \\
\hline \multirow{3}{*}{ Cyclamate } & 1st & 214 & 27.1 & 13.5 & 77.5 & 24.6 & 103 & 860 & 674 \\
& 2nd & N.D. & 367 & N.D. & N.D. & N.D. & N.D. & N.D. & N.D. \\
& 3rd & N.D. & 337 & N.D. & N.D. & 441 & N.D. & N.D. & 3467 \\
\hline \multirow{3}{*}{ Saccharin } & 1st & 47.4 & 121 & 36.9 & 11.9 & N.D. & 273 & N.D. & N.D. \\
& 2nd & 96.7 & 1156 & 114 & 68.1 & 116 & 286 & 87.4 & 135 \\
& 3rd & 204 & 97.8 & 56.5 & 173 & 236 & 199 & 12.7 & 88.9 \\
\hline
\end{tabular}

N.D.: Not Detected.

For comparing with the acesulfame concentrations $(8.1-2690 \mathrm{ng} / \mathrm{L})$, the nitrate- $\mathrm{N}$ concentrations (1.8-29.2 mg/L) were examined, which were detected in 29 wells during October 2014 [43]. Both acesulfame and nitrate-N showed similarly high concentrations in the residential zone, moving towards the stream in the northern region (Figure 2). Spatially, a higher concentration of acesulfame was similar to the nitrate-nitrogen concentration [65]; this showed levels in excess of Korea's drinking water criterion for nitrate- $\mathrm{N}$ concentration $(10 \mathrm{mg} / \mathrm{L})$ at 17 of the 29 wells, with a mean value of $12.72 \mathrm{mg} / \mathrm{L}$ and a median value of $12.6 \mathrm{mg} / \mathrm{L}$ (Table 7 ).

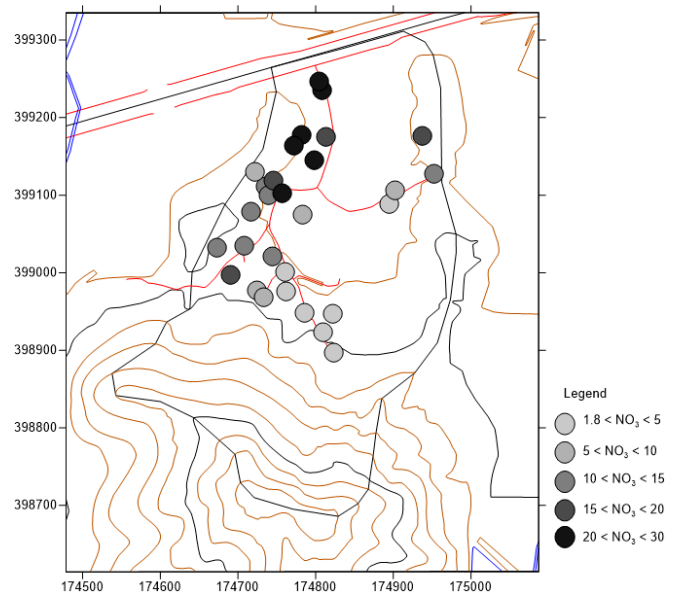

(a)

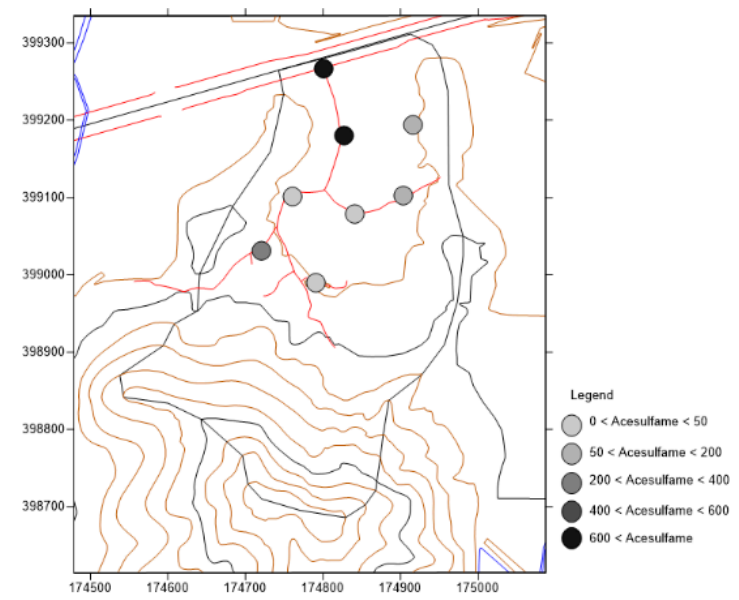

(b)

Figure 2. The distribution of the concentration of (a) nitrate-N and (b) acesulfame.

Table 7. The concentrations of nitrate-N (unit: $\mathrm{mg} / \mathrm{L}$ ).

\begin{tabular}{ccccccccccc}
\hline Well & S-01 & S-02 & S-03 & S-04 & S-05 & S-06 & S-07 & S-08 & S-09 & S-10 \\
\hline Nitrate-N & 1.8 & 3.8 & 4.4 & 3.9 & 4.7 & 6.2 & 8.4 & 4.9 & 11.1 & 12.6 \\
\hline Well & S-11 & S-12 & S-13 & S-14 & S-15 & S-16 & S-17 & S-18 & S-19 & S-20 \\
Nitrate-N & 15.9 & 14.6 & 11.2 & 13.2 & 14.7 & 17.1 & 29.2 & 7.9 & 4.5 & 8.2 \\
\hline Well & S-22 & S-26 & S-27 & S-28 & S-29 & S-30 & S-31 & S-32 & S-33 & \\
Nitrate-N & 14.6 & 19.2 & 20.9 & 17.4 & 26.1 & 24.0 & 23.3 & 20.2 & 5.0 & \\
\hline
\end{tabular}

\subsection{Hydrogeological Results}

For the grain size analysis, soil samples were collected from within a 1-m radius of eight wells. After removing more than $30 \mathrm{~cm}$ of the topsoil, the soil, except for the organic matter, was collected. Using the four empirical equations given in Table 5 and based on a $d_{e}$ between $0.047 \mathrm{~mm}$ (BS-8) and 0.661 
$\mathrm{mm}$ (BS-6) with a mean of $0.194 \mathrm{~mm}$, we obtained mean $K$ values that ranged from $2.678 \times 10^{-5} \mathrm{~m} / \mathrm{s}$ (BS-8) to $1.124 \times 10^{-2} \mathrm{~m} / \mathrm{s}$ (BS-6), with a mean $K$ value of $1.65 \times 10^{-3} \mathrm{~m} / \mathrm{s}$ (Figure 3, Table 8).

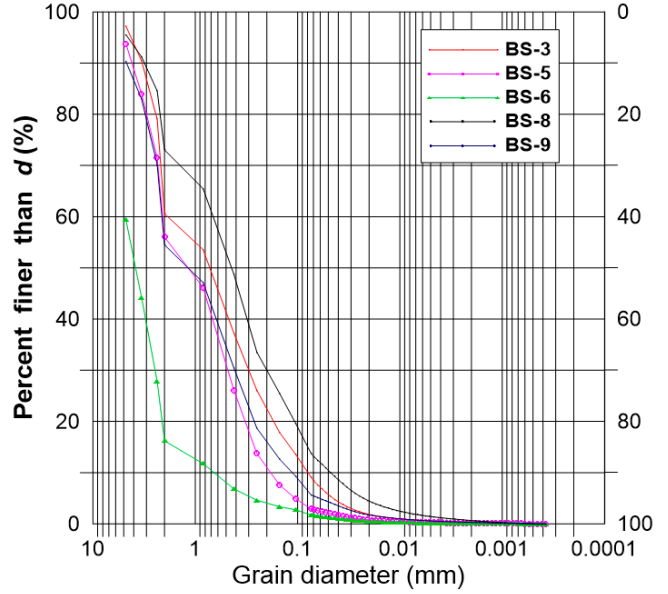

(a)

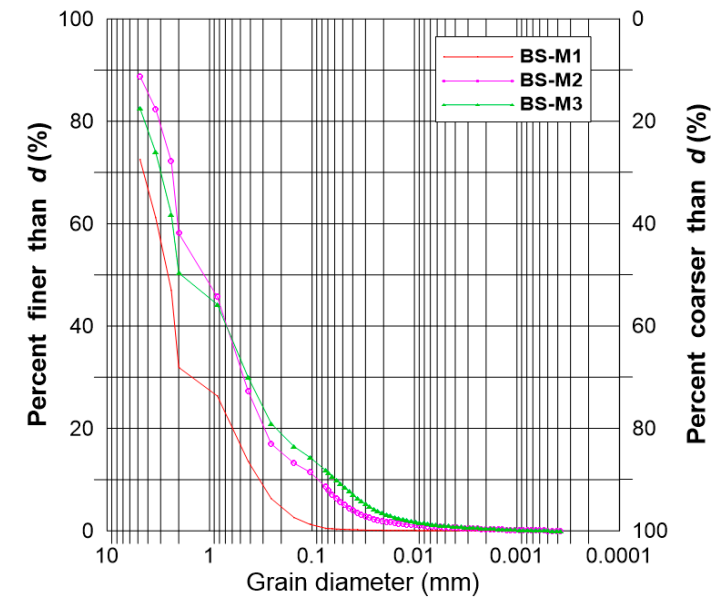

(b)

Figure 3. The results of the grain size analysis. (a) Five single wells and (b) three multi wells.

Table 8. The hydraulic conductivity values based on the empirical grain size analysis (unit: $\mathrm{m} / \mathrm{s}$ ).

\begin{tabular}{|c|c|c|c|c|c|c|c|c|c|c|}
\hline Well & $d_{60}$ & $d_{50}$ & $d_{30}$ & $d_{17}$ & $d_{10}\left(d_{\mathrm{e}}\right)$ & Hazen & Beyer & Sauerbrei & Kozeny & Mean \\
\hline BS-3 & 1.845 & 0.722 & 0.301 & 0.139 & 0.079 & $9.038 \times 10^{-5}$ & $4.282 \times 10^{-5}$ & $1.595 \times 10^{-4}$ & $1.128 \times 10^{-5}$ & $7.599 \times 10^{-5}$ \\
\hline BS-5 & 2.086 & 1.179 & 0.483 & 0.287 & 0.183 & $4.842 \times 10^{-4}$ & $2.831 \times 10^{-4}$ & $6.763 \times 10^{-4}$ & $6.046 \times 10^{-5}$ & $3.760 \times 10^{-4}$ \\
\hline BS-6 & 4.758 & 3.821 & 2.464 & 2.026 & 0.661 & $6.348 \times 10^{-3}$ & $4.165 \times 10^{-3}$ & $3.364 \times 10^{-2}$ & $7.926 \times 10^{-4}$ & $1.124 \times 10^{-2}$ \\
\hline BS-9 & 2.117 & 1.162 & 0.412 & 0.218 & 0.112 & $1.834 \times 10^{-4}$ & $9.303 \times 10^{-5}$ & $3.880 \times 10^{-4}$ & $2.290 \times 10^{-5}$ & $1.718 \times 10^{-4}$ \\
\hline BS-M1 & 3.253 & 2.537 & 1.469 & 0.509 & 0.326 & $1.451 \times 10^{-3}$ & $9.333 \times 10^{-4}$ & $1.792 \times 10^{-3}$ & $1.621 \times 10^{-4}$ & $1.085 \times 10^{-3}$ \\
\hline BS-M2 & 2.050 & 1.135 & 0.467 & 0.249 & 0.087 & $1.103 \times 10^{-4}$ & $5.214 \times 10^{-5}$ & $5.078 \times 10^{-4}$ & $1.377 \times 10^{-5}$ & $1.710 \times 10^{-4}$ \\
\hline
\end{tabular}

According to the slug test analysis at the five wells BS-3, BS-5, BS-6, BS-M2, and BS-M3, the maximum $K$ values were obtained at the BS-5 well: $4.353 \times 10^{-3} \mathrm{~m} / \mathrm{s}$ according to the Hvorslev method and $5.31 \times 10^{-3} \mathrm{~m} / \mathrm{s}$ according to the Bouwer and Rice method, with an average of $4.92 \times 10^{-3} \mathrm{~m} / \mathrm{s}$. On the other hand, at the BS-M3 well, the minimum $K$ values were estimated to be $1.991 \times 10^{-6} \mathrm{~m} / \mathrm{s}$ using the Hvorslev method and $2.067 \times 10^{-6} \mathrm{~m} / \mathrm{s}$ using the Bouwer and Rice method, with an average of $2.029 \times 10^{-6} \mathrm{~m} / \mathrm{s}$ (Table 9 ).

Table 9. The hydraulic conductivity values that were estimated using slug tests (unit: $\mathrm{m} / \mathrm{s}$ ).

\begin{tabular}{cccccc}
\hline Method & BS-3 & BS-5 & BS-6 & BS-M2 & BS-M3 \\
\hline Bouwer and Rice & $1.475 \times 10^{-5}$ & $5.305 \times 10^{-3}$ & $2.074 \times 10^{-3}$ & $2.022 \times 10^{-5}$ & $2.067 \times 10^{-6}$ \\
Hvorslev & $2.261 \times 10^{-6}$ & $4.353 \times 10^{-3}$ & $2.622 \times 10^{-3}$ & $1.963 \times 10^{-5}$ & $1.991 \times 10^{-6}$ \\
Mean & $1.868 \times 10^{-5}$ & $4.920 \times 10^{-3}$ & $2.348 \times 10^{-3}$ & $1.992 \times 10^{-5}$ & $2.029 \times 10^{-6}$ \\
\hline
\end{tabular}

A multi-well tracer test was performed in order to evaluate the connectivity between the two test wells and the diffusion coefficient in the geological formations. A NaCl injection solution was instantaneously injected into the injection well (BS-6), and changes in the EC and salinity were monitored at the observation well (BS-8) using a CTD (Conductivity, Temperature, Depth)-diver; the wells were $\sim 110 \mathrm{~m}$ apart. Changes in the EC and salinity were detected $72 \mathrm{~min}$ after the injection, and they persisted for $1032 \mathrm{~min}$. The maximum EC was $0.004 \mathrm{mS} / \mathrm{cm}$, and the maximum salinity was 0.003 PSU (Practical Salinity Unit). After $1104 \mathrm{~min}$, the EC and salinity rapidly decreased and returned to the background concentration. As a result of the tracer test analysis, the longitudinal dispersivity and solute velocity were estimated to be $12.3 \mathrm{~m}$ and $2.76 \times 10^{-3} \mathrm{~m} / \mathrm{s}$, respectively. 


\subsection{Groundwater Modeling}

In order to simulate the behavior of groundwater pollutants, a numerical model was generated according to the following steps: data acquisition and hydrogeological characterization, conceptualization, calibration, and prediction. First, the steady-state groundwater flow was modeled, then the transport of acesulfame in the groundwater was included using the MT3DMS module in Visual MODFLOW ver. 2014.1. This revealed the groundwater pollution in the recharge, middle, and discharge areas.

\subsubsection{The Conceptual Model and Input Parameters}

The conceptual model was built with $43,776(=152 \times 72 \times 4)$ cells. The geological profile was based on data from right wells (Table 10): The study area consists of a landfill layer, agricultural soil, alluvial deposit, weathered soil, weathered rock, and soft rock. Based on the geological profile, the model's layers were defined as Layer 1 (a landfill layer, agricultural soil, an alluvial deposit, and weathered soil), Layer 2 (weathered rock), Layer 3 (soft rock), and Layer 4 (fresh rock). Irrigation drainage occurs through a drainage channel from the southern hilly zone to the northeastern region.

Table 10. The well locations, groundwater levels, and acesulfame concentrations.

\begin{tabular}{ccccc}
\hline Well & X & Y & $\begin{array}{c}\text { Observed Head } \\
\text { (a m.s.1.) }\end{array}$ & $\begin{array}{c}\text { Acesulfame } \\
\text { Concentration (ng/L) }\end{array}$ \\
\hline BS-3 & $174,790.728$ & $398,990.117$ & 39.44 & 25.8 \\
BS-5 & $174,904.162$ & $399,102.697$ & 36.19 & 17.9 \\
BS-6 & $174,840.516$ & $399,078.763$ & 36.52 & 11.7 \\
BS-8 & $174,916.284$ & $399,193.849$ & 35.47 & 38.1 \\
BS-9 & $174,800.598$ & $399,266.799$ & 28.88 & 330 \\
BS-M1 & $174,720.349$ & $399,030.521$ & 42.88 & 40.4 \\
BS-M2 & $174,760.159$ & $399,100.998$ & 36.45 & 8.1 \\
BS-M3 & $174,826.636$ & $399,180.238$ & 34.59 & 345 \\
\hline
\end{tabular}

The external boundary was set to be the Neman no-flow boundary condition. For the internal boundary conditions, the stream boundary was set to be the drainage channel in the southern hilly zone (that runs along the village and discharge area (Figure 4a)). Each stream boundary's thickness, width, and stream conductance was $0.2 \mathrm{~m}, 0.5 \mathrm{~m}$, and $1 \times 10^{-5} \mathrm{~m} / \mathrm{s}$, respectively. The observed groundwater levels at the eight observation wells (that were converted to an average mean sea level) were used as the inputs for the model.

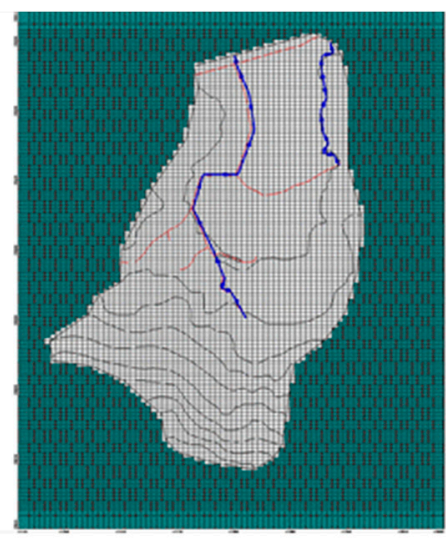

(a)

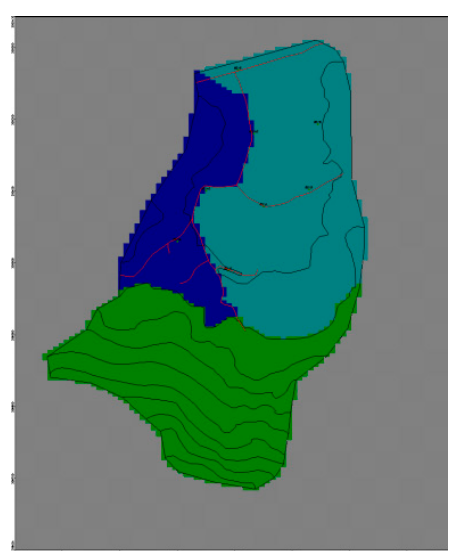

(b)

Figure 4. The (a) boundary conditions and (b) hydraulic conductivity values in the hilly zone (green color), the residential zone (blue color), and the agricultural zone (blue-green color). 
Based on the results of the slug test, the $K$, storativity, effective porosity, and recharge rate values were input differently for the hilly zone, the residential zone, and the agricultural zone (Figure $4 \mathrm{~b}$, Table 11). The longitudinal dispersivity (that was obtained by the tracer test analysis) of $12.7 \mathrm{~m}$, as well as the concentration of acesulfame on 22 May 2017, was also entered into the model.

Table 11. The input values of the hydraulic parameters for the different zones.

\begin{tabular}{ccccc}
\hline Zone & $\boldsymbol{K}(\mathbf{m} / \mathbf{s})$ & Storativity & Recharge $(\mathbf{m m} /$ year) & Effective Porosity \\
\hline Hilly & $7.926 \times 10^{-4}-1.710 \times 10^{-2}$ & $1 \times 10^{-5}$ & 280 & 0.15 \\
Residential & $1.991 \times 10^{-6}-6.126 \times 10^{-5}$ & $5 \times 10^{-5}$ & 120 & 0.15 \\
Agricultural & $2.678 \times 10^{-5}-4.920 \times 10^{-3}$ & $1 \times 10^{-5}$ & 200 & 0.15 \\
\hline
\end{tabular}

\subsubsection{The Calibration and Steady-State Simulation}

The simulated water levels were calibrated to the observed levels by varying the values of $K$ over the range obtained in the slug test and by the result of the steady-state simulation (Table 12). The groundwater level data from the BS-3, BS-M1, BS-M2, and BS-M3 wells were excluded from the calibration because those wells were located in a residential zone and were being actively pumped. The calibration was completed with a correlation coefficient of 0.903 and a confidence interval within 95\%; the residuals from the calibration ranged from $-3.4-0.63 \mathrm{~m}$, with an average of $-1.28 \mathrm{~m}$ (Figure $5 \mathrm{a}$, Table 13).

Table 12. The hydraulic conductivity values from the steady-state model's calibration.

\begin{tabular}{cc}
\hline Zone & $\boldsymbol{K}(\mathbf{m} / \mathbf{s})$ \\
\hline Hilly & $9.354 \times 10^{-4} \mathrm{~m} / \mathrm{s}$ \\
Residential & $1.354 \times 10^{-5} \mathrm{~m} / \mathrm{s}$ \\
Agricultural & $3.588 \times 10^{-5} \mathrm{~m} / \mathrm{s}$ \\
\hline
\end{tabular}

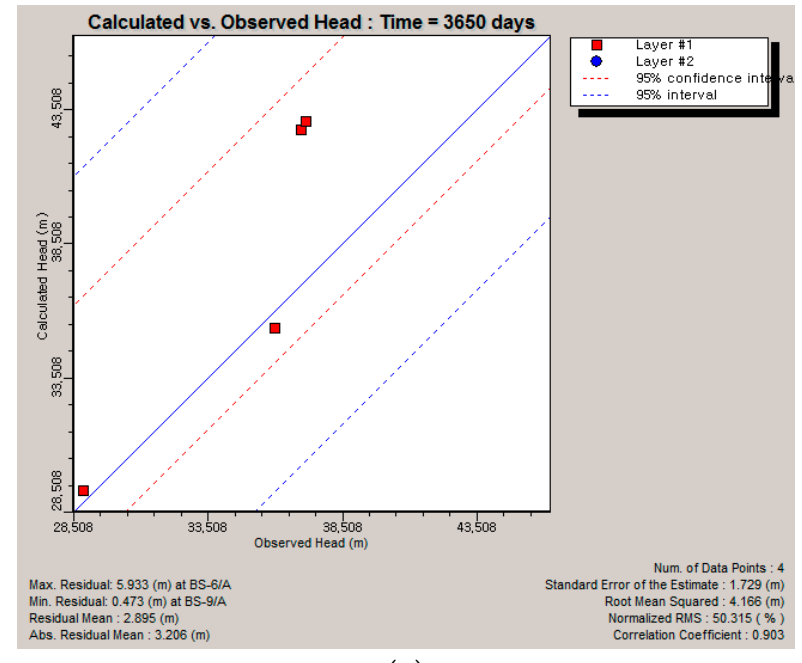

(a)

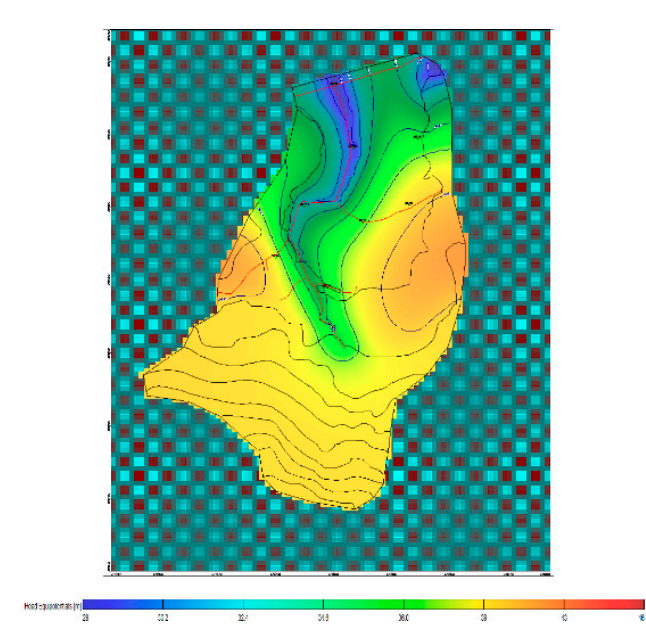

(b)

Figure 5. The (a) calculated versus observed levels and (b) groundwater level contours in the steady-state. 
Table 13. The results of the steady-state model's calibration (unit: a m.s.l., m).

\begin{tabular}{cccc}
\hline Well & Observed Head & Calculated Head & Residual \\
\hline BS-5 & 36.19 & 39.59 & -3.40 \\
BS-6 & 36.52 & 37.73 & -1.21 \\
BS-8 & 35.47 & 36.60 & -1.13 \\
BS-9 & 28.88 & 28.25 & 0.63 \\
\hline
\end{tabular}

The steady-state model showed that groundwater principally moves from south to north along the stream boundary and then converges to the northeast. The groundwater levels were $38-28 \mathrm{~m}$ a m.s.l. The mean groundwater velocity through the forward particle tracking was $5.2 \times 10^{-6} \mathrm{~m} / \mathrm{s}$; the particles were predicted to flow out through the stream boundary to the north and northeast.

\subsubsection{Prediction of the Acesulfame's Spread}

According to the particle tracking, the mean velocity of the groundwater over the entire study area is $5.2 \times 10^{-6} \mathrm{~m} / \mathrm{s}$. Through forward particle tracking, we see that particles flow through the stream boundary to the north and northeast discharge boundaries (Figure 6). The particles from wells BS-5, BS-8, and BS-3 flow fast $\left(4.267 \times 10^{-8}-1.559 \times 10^{-6} \mathrm{~m} / \mathrm{s}\right)$, and the particles from the wells BS-M1 and BS-M2 (which are located in the residential zone) have a low velocity $\left(2.158 \times 10^{-9}-2.755 \times 10^{-7} \mathrm{~m} / \mathrm{s}\right)$. Forward particle tracking was carried out for the central residential zone (where acesulfame is probably derived); hence, the groundwater flow from the residential zone to the stream boundary was estimated. In the eastern part of the residential zone, the particles usually flow into the drain conduit with a relatively high velocity. However, in the western part, where many houses and the town hall are concentrated together in the village, the particles move slowly. Therefore, pollution in the western drain channel that heads east is expected to be more serious than the pollution along the eastern drain channel (Figure 7).

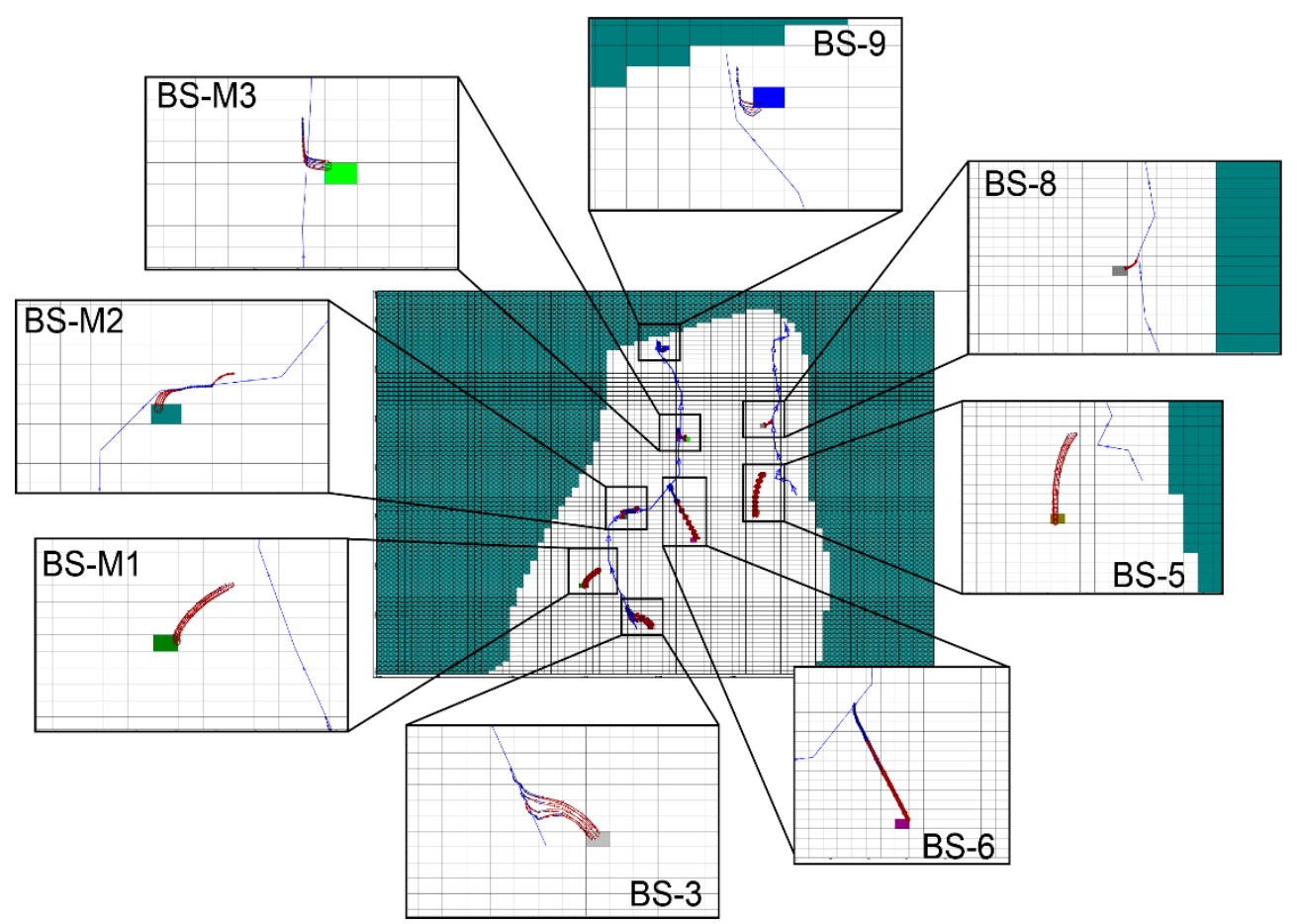

Figure 6. Forward particle tracking of the movement of particles from the wells. 


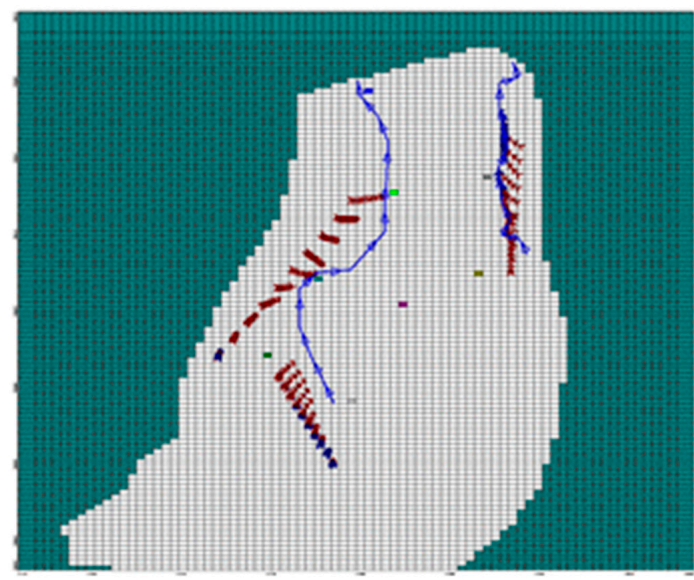

Figure 7. Particle tracking from the stream boundary.

Subsequently, a 10-year transient modeling with the MT3DMS module was performed to estimate the areal distribution of the acesulfame concentration. The concentration of acesulfame at each well was given an initial value of $102.1 \mathrm{ng} / \mathrm{L}$, which was obtained from the water quality analysis of the samples in the first survey in 2017. Using the MT3DMS model, we observed that, in Years 1-3, acesulfame actively spread from the BS-9 and BS-M3 wells and outflowed through the stream boundary (Figure 8). Then, the concentration of acesulfame attained equilibrium downstream of the stream boundary and started to decrease in the agricultural region after approximately five years. After 10 years, the acesulfame in the agricultural zone, and in the hilly zone, was mostly discharged through the stream boundary, while the acesulfame in the central residential zone remained close to the initial state.

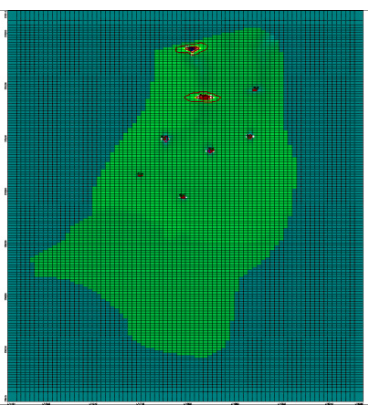

(a)

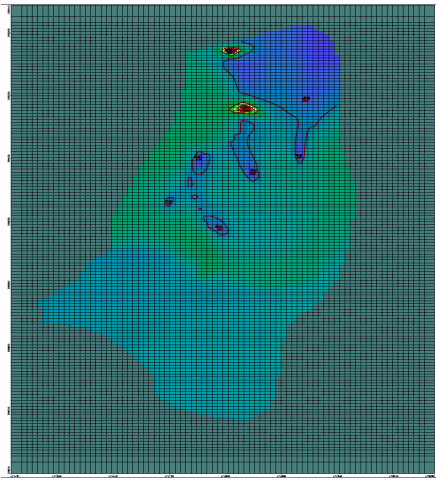

(d)

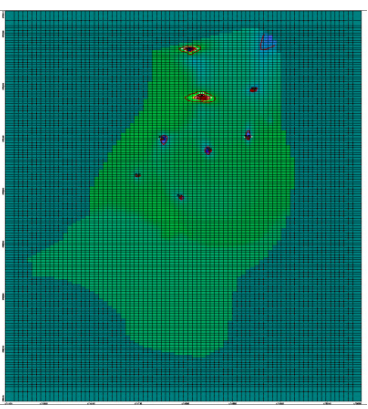

(b)

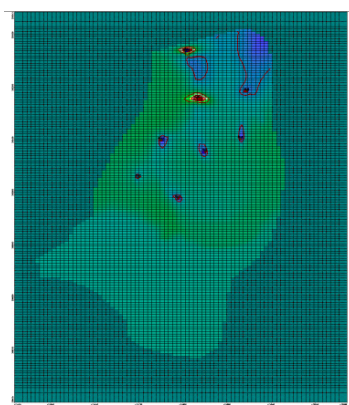

(c)

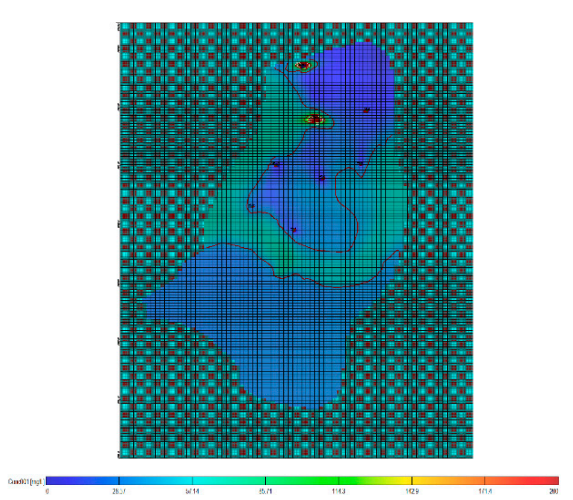

(e)

Figure 8. The MT3DMS model of the areal concentration of acesulfame after (a) 1 year, (b) 3 years, (c) 5 years, (d) 7 years, and (e) 10 years. 


\section{Discussion}

A typical indicator of pollution in groundwater is nitrate- $\mathrm{N}$, which commonly derives from livestock wastewater, manure, domestic wastewater, pesticides, and agricultural fertilizers, mainly in agricultural and livestock areas. The seasonality of nitrogen concentrations in groundwater occurs in agricultural areas in Europe, showing the highest nitrogen concentrations in spring after winter freezing with a small vegetation cover, as well as in the areas of the high level of nitrogen application [32]. According to the NIER's 2016 survey in Korea [65], sulfamethoxazole (antibiotics), oxfendazole (insect repellent), and carbofuran (pesticides) were only detected in agricultural and livestock areas and may enter the groundwater as a result of agricultural and animal farm activities.

Acesulfame is recognized as a pollutant in groundwater and surface water that originates from sewage inflow [12,13]. The concentration of acesulfame in the groundwater in urban areas was found to be between 3.5- and 67-times higher than that in agricultural and livestock areas [65]. Compared to nitrate-N, acesulfame is highly persistent and has a low removal rate at the treatment site [66]. At present, the toxicity of acesulfame is not clear, but acesulfame may be an appropriate indicator of groundwater contamination originating from man-made sewage.

The comparison of the nitrate-N water quality analysis with the acesulfame water quality analysis, along with the groundwater modeling, verified that acesulfame is a potential indicator for the contamination of groundwater in rural areas in Korea. Hence, acesulfame has been confirmed to be a very useful indicator for the detection of sources of man-made pollution. Acesulfame may be a useful tool to design regulations, management measures, and policies for groundwater in rural areas where people use large amounts of artificial sweeteners.

\section{Conclusions}

In this study, acesulfame was confirmed to be the most common artificial sweetener that contaminates groundwater. Acesulfame showed high concentrations (8.1-2690 ng/L) in the residential zone, as it is known to be a pollutant in groundwater and surface water that originates from sewage inflow. Besides this, the nitrate-N concentrations (1.8-29.2 mg/L) displayed a similar distribution pattern to the acesulfame concentrations. By the MT3DMS and particle tracking modeling, acesulfame actively spreads from the BS-9 and BS-M3 wells in the residential zone and outflows through the stream boundary, indicating that it discharges in the agricultural and hilly zones.

The acesulfame concentration in the groundwater was evaluated using particle tracking in Visual MODFLOW with the MT3DMS module. Forward particle tracking showed that the groundwater flows relatively rapidly in the agricultural land, flows slowly in the western residential zone, and finally flows through the stream boundary to the northern region. According to the MT3DMS simulation, acesulfame spreads across the model domain over 1-3 years, and the concentration gradually decreases after $\sim 5$ years. Over the 10-year simulation period, acesulfame escaped through the stream boundary in the northern part of the study area, while it accumulated in the residential zone and downstream of the stream boundary. Therefore, it is anticipated that the groundwater' acesulfame contamination level may be higher in the western drainage channel than in the eastern drainage channel.

Author Contributions: Conceptualization, C.-M.L. and S.-Y.H.; methodology, S.-Y.H. and J.-E.O.; software, C.-M.L. and S.-M.Y.; validation M.K. and H.K.K.; formal analysis, C.-M.L., J.-E.O. and S.-M.Y.; investigation, C.-M.L. and S.-M.Y.; resources, M.K.; data curation, H.K.K.; writing, original draft preparation, C.-M.L. and S.-Y.H.; writing, review and editing, S.-Y.H.; visualization, C.-M.L.; supervision, S.-Y.H.; project administration, S.-Y.H.; funding acquisition, S.-Y.H.

Funding: This research was funded by National Research Foundation of Korea (NRF) under the Ministry of Science and ICT (NRF-2017R1A2B2009033), as well as by the National Institute of Environment Research (NIER), funded by the Ministry of Environment (MOE) of Korea (NIER-2017-03-02-019).

Conflicts of Interest: The authors declare no conflict of interest. 


\section{References}

1. Subedi, B.; Kannan, K. Fate of artificial sweeteners in wastewater treatment plants in New York State, USA. Environ. Sci. Technol. 2014, 48, 13668-13674. [CrossRef] [PubMed]

2. Lange, F.T.; Scheurer, M.; Brauch, H.J. Artificial sweeteners-A recently recognized class of emerging environmental contaminants: A review. Anal. Bioanal. Chem. 2012, 403, 2503-2518. [CrossRef] [PubMed]

3. Van Stampvoort, D.R.; Roy, J.W.; Brown, S.J.; Bickerton, G. Artificial sweeteners as potential tracers in groundwater in urban environments. J. Hydrol. 2011, 401, 126-133. [CrossRef]

4. Loos, R.; Gawlik, B.M.; Boettcher, K.; Locoro, R.; Contini, S.; Bidoglio, G. Sucralose screening in European surface waters using a solid-phase extraction-liquid chromatography-triple quadrupole mass spectrometry method. J. Chromatogr. A 2009, 1216, 1126-1131. [CrossRef] [PubMed]

5. Buerge, I.J.; Buser, H.R.; Kahle, M.; Muller, M.D.; Poiger, T. Ubiquitous occurrence of the artificial sweetener acesulfame in the aquatic environment: An ideal chemical marker of domestic wastewater in groundwater. Environ. Sci. Technol. 2009, 43, 4381-4385. [CrossRef] [PubMed]

6. Arbeitsgemeinschaft Wasserwerke Bodensee Rhein (AWBR). 42. Jahresbericht 2010; Geschäftsstelle der Arbeitsgemeinschaft Wasserwerke Bodensee-Rhein (AWBR): Freiburg, Germany, 2010.

7. Mead, R.N.; Morgan, J.B.; Avery, G.B.; Kieber, R.J.; Kirk, A.M.; Skrabal, S.A.; Willey, J.D. Occurrence of the artificial sweetener sucralose in coastal and marine waters of the United States. Mar. Chem. 2009, 116, $13-17$. [CrossRef]

8. Storck, F.R.; Skark, C.; Remmier, F.; Brauch, H.J. Environmental fate and behavior of acesulfame in laboratory experiments. Water Sci. Technol. 2016, 74, 2832-2842. [CrossRef] [PubMed]

9. Mawhinney, D.B.; Young, R.B.; Vanderford, B.J.; Borch, T.; Snyder, S.A. Artificial sweetener sucralose in US drinking water systems. Environ. Sci. Technol. 2011, 45, 8716-8722. [CrossRef] [PubMed]

10. Soh, L.; Connors, K.A.; Brooks, B.W.; Zimmerman, J. Fate of sucralose through environmental and water treatment processes and impact on plant indicator species. Environ. Sci. Technol. 2011, 45, 1363-1369. [CrossRef] [PubMed]

11. Dep, P.; Debnath, P.; Denis, A.F.; Lepcha, O.T. Variability of soil physicochemical properties at different agroecological zones of Himalayan region: Sikkim, India. Environ. Dev. Sustain. 2018, 1-19. [CrossRef]

12. Tran, N.H.; Hu, J.; Li, J.; Ong, S.L. Suitability of artificial sweeteners as indicators of raw wastewater contamination in surface water and groundwater. Water Res. 2014, 48, 443-456. [CrossRef] [PubMed]

13. Wolf, L.; Zwiener, C.; Zemann, M. Tracking artificial sweeteners and pharmaceuticals introduced into urban groundwater by leaking sewer networks. Sci. Total Environ. 2012, 430, 8-19. [CrossRef] [PubMed]

14. Morasch, B. Occurrence and dynamics of micropollutants in a karst aquifer. Environ. Pollut. 2013, 173, 133-137. [CrossRef] [PubMed]

15. Cabeza, Y.; Candela, L.; Ronen, D.; Teijon, G. Monitoring the occurrence of emerging contaminants in treated wastewater and groundwater between 2008 and 2010. J. Hazard. Mater. 2012, 239, 32-39. [CrossRef] [PubMed]

16. López-Serna, R.; Jurado, A.; Vázquez-Suñé, E.; Carrera, J.; Petrović, M.; Barceló, D. Occurrence of 95 pharmaceuticals and transformation products in urban groundwaters underlying the metropolis of Barcelona, Spain. Environ. Pollut. 2013, 174, 305-315. [CrossRef] [PubMed]

17. Schaider, L.A.; Rudel, R.A.; Ackerman, J.M.; Dunagan, S.C.; Brody, J.G. Pharmaceuticals, perfluorosurfactants, and other organic wastewater compounds in public drinking water wells in a shallow sand and gravel aquifer. Sci. Total Environ. 2014, 468, 384-393. [CrossRef] [PubMed]

18. Tong, L.; Huang, S.; Wang, Y.; Liu, H.; Li, M. Occurrence of antibiotics in the aquatic environment of Jianghan Plain, central China. Sci. Total Environ. 2014, 497, 180-187. [CrossRef] [PubMed]

19. National Institute of Environmental Research. Investigation and Survey of Residual Drug Substance Analysis Method (IV); National Institute of Environmental Research: Incheon, Korea, 2011; pp. 1-358.

20. Animal and Plant Quarantine Agency. Investigation of Veterinary Antimicrobial Drug Residues and Their Behavior in Animal Farming Environment; Animal and Plant Quarantine Agency: Gimcheon, Korea, 2010; pp. 683-704.

21. Future Market Insights (FMI). Animal Healthcare Market: Global Industry Analysis and Opportunity Assessment 2015-2020; Future Market Insights: London, UK, 2015. 
22. Hu, X.; Zhou, Q.; Luo, Y. Occurrence and source analysis of typical veterinary antibiotics in manure, soil, vegetables and groundwater from organic vegetable bases, northern China. Environ. Pollut. 2010, 158, 2992-2998. [CrossRef] [PubMed]

23. Yao, L.; Wang, Y.; Tong, L.; Deng, Y.; Li, Y.; Gan, Y.; Guo, W.; Dong, C.; Duan, Y.; Zhao, K. Occurrence and risk assessment of antibiotics in surface water and groundwater from different depths of aquifers: A case study at Jianghan Plain, central China. Ecotoxicol. Environ. Saf. 2017, 135, 236-242. [CrossRef] [PubMed]

24. Balzer, F.; Zühlke, S.; Hannappel, S. Antibiotics in groundwater under locations with high livestock density in Germany. Water Sci. Technol. Water Supply 2016, 16, 1361-1369. [CrossRef]

25. World Health Organization (WHO). Pharmaceuticals in Drinking-Water; World Health Organization: Geneva, Switzerland, 2011; pp. 1-52.

26. Kümmerer, K. Antibiotics in the aquatic environment-A review-Part I. Chemosphere 2009, 75, 417-434. [CrossRef] [PubMed]

27. U.S. Environmental Protection Agency. Contaminants of Emerging Concern including Pharmaceuticals and Personal Care Products; U.S. Environmental Protection Agency, Office of Water: Washington, DC, USA, 2005.

28. Bartelt-Hunt, S.; Snow, D.D.; Damon-Powell, T.; Miesbach, D. Occurrence of steroid hormones and antibiotics in shallow groundwater impacted by livestock waste control facilities. J. Contam. Hydrol. 2011, 123, 94-103. [CrossRef] [PubMed]

29. Batt, A.L.; Snow, D.D.; Aga, D.S. Occurrence of sulfonamide antimicrobials in private water wells in Washington County, Idaho, USA. Chemosphere 2006, 64, 1963-1971. [CrossRef] [PubMed]

30. Watanabe, N.; Bergamaschi, B.A.; Loftin, K.A.; Meyer, M.T.; Harter, T. Use and environmental occurrence of antibiotics in freestall dairy farms with manured forage fields. Environ. Sci. Technol. 2010, 44, 6591-6600. [CrossRef] [PubMed]

31. Barnes, K.K.; Kolpin, D.W.; Meyer, M.T.; Thurman, E.M.; Furlong, E.T.; Zaugg, S.D.; Barber, L.B. Water-Quality Data for Pharmaceuticals, Hormones, and Other Organic Wastewater Contaminants in U.S. Streams, 1999-2000; U.S. Environmental Protection Agency: Iowa City, IA, USA, 2002.

32. Lawniczak, A.E.; Zbierska, J.; Nowak, B.; Achtenberg, K.; Grześkowiak, A.; Kanas, K. Impact of agriculture and land use on nitrate contamination in groundwater and running waters in central-west Poland. Environ. Monit. Assess. 2016, 188, 172. [CrossRef] [PubMed]

33. Appelo, C.A.J.; Postma, D. Geochemistry, Groundwater and Pollution, 2nd ed.; A.A. Balkema Publisher: Amsterdam, The Netherlands, 1996; pp. 271-279.

34. Lolan, B.T.; Ruddy, B.C.; Hitt, K.J.; Helsel, D.R. Risk of nitrate in groundwaters of the United States-A national perspective. Environ. Sci. Technol. 1997, 31, 2229-2236.

35. Pastén-Zapara, E.; Ledesma-Ruiz, R.; Harter, T.; Ramírez, A.I.; Maglknecht, J. Assessment of sources and fate of nitrate in shallow groundwater of an agricultural area by using a multi-tracer approach. Sci. Total Environ. 2014, 470-471, 855-864. [CrossRef] [PubMed]

36. Kim, K.H.; Yun, S.T.; Chae, G.T.; Choi, B.Y.; Kim, S.O.; Kim, K.J.; Kim, H.S.; Lee, C.W. Nitrate contamination of alluvial groundwaters in the Keum river watershed area: Source and behaviors of nitrate, and suggestion to secure water supply. J. Eng. Geol. 2002, 12, 471-484.

37. Cheong, J.Y.; Hamm, S.Y.; Lee, J.H.; Lee, K.S.; Woo, N.C. Groundwater nitrate contamination and risk assessment in an agricultural area, South Korea. Environ. Earth Sci. 2012, 66, 1127-1136. [CrossRef]

38. Kim, J.W.; Cho, M.Y.; Jee, B.; Park, M.A.; Kim, N.Y. Administration and use of aquaculture drugs in Korea. J. Fish Pathol. 2014, 27, 67-75. [CrossRef]

39. Yoon, Y.; Ryu, J.; Oh, J.; Choi, B.G.; Snyder, S.A. Occurrence of endocrine disrupting compounds, pharmaceuticals, and personal care products in the Han River (Seoul, South Korea). Sci. Total Environ. 2010, 408, 636-643. [CrossRef] [PubMed]

40. National Institute of Environmental Research. Study on the Emission Source and Behavior of Medicinal Substances in the Environment; National Institute of Environmental Research: Incheon, Korea, 2011; pp. 1-282.

41. Ji, K.; Kim, S.; Han, S.; Seo, J.; Lee, S.; Park, Y.; Choi, K. Risk assessment of chlortetracycline, oxytetracycline, sulfamethazine, sulfathiazole, and erythromycin in aquatic environment: Are the current environmental concentrations safe? Ecotoxicology 2012, 21, 2031-2050. [CrossRef] [PubMed]

42. Creed, I.F.; Band, L.E.; Foster, N.W.; Morrison, I.K.; Nicolson, J.A.; Semkin, R.S.; Jeffries, D.S. Regulation of nitrate-N release from temperate forests: A test of the $\mathrm{N}$ flushing hypothesis. Water Resour. Res. 1996, 32, 3337-3354. [CrossRef] 
43. National Institute of Environmental Research. A study of Optimal Management Measures for Securing Safe Groundwater; National Institute of Environmental Research: Incheon, Korea, 2015; pp. 1-302.

44. Chai, J.C.; Agung, P.M.A.; Hino, T.; Igaya, T.; Cater, J.P. Estimating hydraulic conductivity from piezocone soundings. Géotechnique 2011, 61, 699-708. [CrossRef]

45. Chai, J.C.; Chanmee, N. A modified method for estimating permeability of clayey soils based on piezocone sounding results. Can. Geotech. J. 2018, 55, 1268-1281. [CrossRef]

46. Shen, S.L.; Wang, J.P.; Wu, H.N.; Xu, Y.S.; Ye, G.L.; Yin, Z.Y. Evaluation of hydraulic conductivity for both marine and deltaic deposit based on piezocone test. Ocean Eng. 2015, 110, 174-182. [CrossRef]

47. Wu, Y.X.; Shen, S.L.; Yuan, D.J. Characteristics of dewatering induced drawdown curve under blocking effect of retaining wall in aquifer. J. Hydrol. 2016, 539, 554-566. [CrossRef]

48. Wu, Y.X.; Shen, J.S.; Cheng, W.C.; Hino, T. Semi-analytical solution to pumping test data with barrier, wellbore storage, and partial penetration effects. Eng. Geol. 2017, 226, 44-51. [CrossRef]

49. Cheong, J.Y.; Hamm, S.Y.; Kim, H.S.; Ko, E.J.; Yang, K.; Lee, J.H. Estimating hydraulic conductivity using grain-size analyses, aquifer tests, and numerical modeling in a riverside alluvial system in South Korea. Hydrogeol. J. 2008, 16, 1129-1143. [CrossRef]

50. Du, Y.J.; Jiang, N.J.; Shen, S.L.; Jin, F. Experimental investigation of influence of acid rain on leaching and hydraulic characteristics of cement-based solidified/stabilized lead contaminated clay. J. Hazard. Mater. 2012, 30, 225-226. [CrossRef] [PubMed]

51. Du, Y.J.; Fan, R.D.; Liu, S.Y.; Reddy, K.R.; Jin, F. Workability, compressibility and hydraulic conductivity of zeolite-amended clayey soil/calcium-bentonite backfills for slurry-trench cutoff walls. Eng. Geol. 2015, 195, 258-268. [CrossRef]

52. Kasenow, M. Determination of Hydraulic Conductivity from Grain Size Analysis; Water Resources Publications LLC: Denver, CO, USA, 2002; pp. 47-84.

53. Hazen, A. Some Physical Properties of Sands and Gravels: With Special Reference to Their Use in Filtration; Annual Report; Massachusetts State Board of Health: Boston, MA, USA, 1892; pp. 539-556.

54. Beyer, W. On the Determination of Hydraulic Conductivity of Gravels and Sands from Grain-Size Distribution; Wasserwirtschaft-Wassertechnik: Berlin, Germany, 1964; Volume 14, pp. 165-169.

55. Kozeny, J. Ueber kapillare leitung des wassers im boden. Sitzungsber Acad. Wiss. Wien 1927, 136, 271-306.

56. Vukovic, M.; Soro, A. Determination of hydraulic conductivity of porous media from grain-size composition; Water Resources Publications: Littleton, CO, USA, 1992; pp. 1-83.

57. Hvorslev, M.J. Time Lag and Soil Permeability in Ground Water Observations; US Army Corps of Engineers, Waterway Experimentation Station: Vicksburg, MI, USA, 1951; pp. 1-50.

58. Bouwer, H.; Rice, R.C. A slug test for determining hydraulic conductivity of unconfined aquifers with completely or partially penetrating wells. Water Resour. Res. 1976, 12, 423-428. [CrossRef]

59. Cooper, H.H.; Bredehoeft, J.D.; Papadopulos, S.S. Response of a finite-diameter well to an instantaneous charge of water. Water Resour. Res. 1967, 3, 263-269. [CrossRef]

60. Hubbard, E.F.; Kilpatrick, F.A.; Martens, L.A.; Wilson, J.F. Measurement of Time of Travel and Dispersion in Streams by Dye Tracing - Techniques of Water-Resources Investigations of the US Geological Survey; U.S. Geological Survey: Washington, DC, USA, 1982; pp. 1-52.

61. Gurierrez, A.; Klinka, T.; Thiéry, D.; Buscarlet, E.; Binet, S.; Jozja, N.; Défarge, C.; Leclerc, B.; Fécamp, C.; Ahumada, Y.; Elsass, J. TRAC, a collaborative computer tool for tracer-test interpretation. EPJ Web Conf. 2013, 50, 1-8. [CrossRef]

62. McDonald, M.G.; Harbaugh, A.W. A Modular Three-dimensional Finite-Difference Ground-water Flow Model; Techniques of Water-Resources Investigations of the United States Geological Survey, Book 6, Chapter A1; U.S. Geological Survey: Washington, DC, USA, 1988.

63. Zheng, P.C.; Wang, P. MT3DMS: A Modular Three-Dimensional Multispecies Transport Model for Simulation of Advection, Dispersion, and Chemical Reactions of Contaminants in Groundwater Systems; Documentation and User's Guide; US Army Corps of Engineers: Washington, DC, USA, 1999; pp. 1-219.

64. Clement, T.P. RT3D-A Modular Computer Code for Simulating Reactive Multi-Species Transport in 3-Dimensional Groundwater Aquifer; U.S. Department of Energy: Washington, DC, USA, 1997; pp. 1-59.

65. National Institute of Environmental Research. A study on the Tracking Technique of Groundwater Contamination in Korea (I); National Institute of Environmental Research: Incheon, Korea, 2016; pp. 1-101. 
66. Buerge, I.J.; Buster, H.R.; Kahle, M.; Müller, M.D.; Poiger, T. The artificial sweetener acesulfame as marker of domestic wastewater in groundwater. In Proceedings of the Groundwater Quality Management in a Rapidly Changing World, 7th International Groundwater Quality Conference, Zurich, Switzerland, 13-18 June 2010; Volume 342, pp. 103-106. 